\title{
Career Advancement, School Relations and Support Service Factors as Determinant of Teacher Productivity in Public Secondary Schools in Oyo State, Nigeria
}

\author{
Emmanuel Olusola Adu ${ }^{1, *}$, Oshati Titilola ${ }^{2} \&$ Ifeoma R. Eze $^{1}$ \\ ${ }^{1}$ Faculty of Education, BA ISAGO University College, Botswana \\ ${ }^{2}$ Department of Educational Management, University of Ibadan, Nigeria \\ Corresponding author: Emmanuel Olusola Adu, Faculty of Education, BA ISAGO University \\ College. Botswana, Private bag 149 suite \# 268 kgale view postnet. Gaborone, Botswana \\ Tel: 267-7177-9202Ｆax: (+267) 3957709 E-mail: emmanuel.adu@baisago.co.bw
}

Received: August 18, 2012 Accepted: September 29, 2012 Published: November 1, 2012 doi:10.5296/ije.v4i4.2266 URL: http://dx.doi.org/10.5296/ije.v4i4.2266

This research work is not sponsored by any organization but self-sponsored by the authors

\begin{abstract}
This study investigated the extent to which these factors determine teacher productivity in public secondary schools. The study revealed among others the composite contribution of career advancement factor $(\beta=0.36 ; \mathrm{t}=6.82 ; \mathrm{p}<.05)$; and school relations factor $(\beta=0.13$; $\mathrm{t}=2.59 ; \mathrm{p}<.05)$. On the contrary, support services factor $(\beta=0.09 ; \mathrm{t}=1.87 ; \mathrm{p}>05)$ was not significant in predicting teacher productivity. The factors such as career advancement and school relations factors revealed a positive impact on productiveness and effectiveness of teachers. A good work system should be created by which teachers will maintain high effectiveness level.
\end{abstract}

Keywords: teacher productivity; career advancement; school relation and support service 


\section{Background to the Study}

Improvement in the productivity of Nigerian employees in the different sectors of the economy has remained the recurrent themes of many symposia, conferences and workshops. It is a recognized fact that productivity is a critical factor in socio-economic development of any nation, for it is one of the key determinants of the standard of living of the citizenry. There is therefore no doubt that improved productivity is at the core of the activity of all organizations, suggest that the survival and growth of most human understandings depend to a large extend on the organization level of productivity which itself depends on the productivity of employee.

Workers in any organization are the prime factors that propel the organization. The levels of efficiency and productivity depend on the workers. Ogunsanya (1981) opines that the efficiency with which any school organization can be operated depends on the effectiveness of teachers on the job both as individual and collectively as a team.

Despite the realization of the importance of productivity, there has been and there are still some general slurs and slumps in the employees' efforts and actual performance, the declining productivity level in many organizations have led to widespread criticism about such organizations (Ilori, 1995). Low productivity in the Nigeria's educational system is reflected in general complaints by stakeholders of the primary, secondary and tertiary institutions. According to Akporehe (2011), the main objective of the secondary school education is to train individuals to read, write and be numerically literate but in recent times, it is noteworthy that many secondary school leavers can neither read nor write appropriately. Judging from the products of the Nigerian secondary schools, the gateway to tertiary institutions, there is a big question mark on level of performance and the productivity of their teachers. It is also observed that many Nigerians avoid sending their wards to public secondary school, because their products are mostly unable to read and write.

Graduates of the different levels know very little of what they are supposed to have learnt in school. The poor results of school certificate examinations over the years have provided justification for the expressed concerns. According to West African Examination Council (WAEC, 2007), the failure rate for English language in the past five years surpassed that of the percentage of credits scored in Senior School Certificate Examination (SSCE) conducted by it between 2001 and 2005. While in Mathematics, a fluctuating trend was recorded by the candidates during this period. Besides, Punch (2008) reveals that out of a total of 1,369,142 candidates that sat for West African Senior School Certificate Examination (WASSCE) in Nigeria in 2008, only 188,442 representing $13.76 \%$ obtained five credit passes and above in English Language,Mathematics and three other subjects. While 947,945 candidates representing $83 \%$ failed the examination. The analysis suggests that all is not well with students' performance in secondary schools.

However, every poor performance and failures are usually blamed on the workers by the management. Conversely workers often blame the management for productivity related problems. Nevertheless, it has been observed that productivity shortcomings were due to the fact that people were not performing their assigned or expected duties satisfactorily. The 
question that could now be posed is why are those workers not performing their jobs satisfactorily?

Nigerian employees are said to have poor attitude to work, resulting in low level productivity, and the Nigerian educational sector appears to be one of the hardest hit in this poor disposition to work (Umeh 1997). That is why in recent years, secondary education has come under mounting criticisms from parents, opinion leaders, politicians, academia and other well-meaning people. Some critics allege that the standard of secondary school education is too low while others are of the opinion that the entire sector is not as productive and effective as it ought to be. More often than not, teachers are usually the object of such criticisms pertaining to the general decay in the education sector. They are accused of low productivity (Fadipe, 2000; Odunuga and Ajila, 2000).

Observably, in recent years the quality of education in Nigeria, especially in our secondary schools, has been a subject of public concern. The major thrust of such public concern has to do with the falling standard of education and urgent need to redress the situation to avoid further deterioration. Ajayi and Adeosun (2004) attest to this in an address presented at the national workshop on planning and administration for a successful implementation of the UBE programme in Nigeria where he states that a cursory look at the education scenario in Nigeria presents no less a picture of poor quality education and then went on to posit that poor planning models, weak school administration and management, low teacher productivity arising from low teachers' dedication and commitment (morale) to their job accounted for the poor education quality in the country.

Efforts have been made to improve the quality of education in Nigeria. Evidence has shown that the education system in Nigeria is in problem (Abayowa, 2004). Adepoju (2004) contends that of all the problems facing Nigeria education system none is more agonizing and persisted as poor academic performance of students especially of secondary schools at the external examinations conducted by WAEC. Aremu (2000) describes the poor academic performance in the public examination as a system of a pervasive national failure that has been stamped on every phase of our national endeavors. Ezekwesili (2006) also lamented that the Nigeria education can be described as a crises while Ogomudia (2008) points out that the standard of education had fallen to an unacceptable level. Omotosho (2007) concludes that a nation that fails to get its education system right may have its future at stake.

According to Hallak (1990), the quality of education system depends on the quality of its teachers. The National Policy on Education (FME, 2004) in aligning with Hallak (1990) states that no education system could rise above the quality of its teachers. Obayan (2006) avers that a qualified teacher is not necessarily a competent teacher; and a competent teacher may not necessarily be an efficient teacher. One simple measure of teachers' competence and effectiveness is the interaction pattern in the classroom.

Given the above scenario, the importance of good administration and management of the secondary school system becomes imperative. In the secondary school system, the principal is responsible for the administration and management while teaching and learning are carried out primarily by teachers and students respectively. According to Jaiyeoba (2008), the teacher 
occupies a central position in the instructional setting. Adesokan (2000) aptly states this when he asserts that the teacher is the spark and key man in the drive to progress in our educational enterprise. Expectedly, the teacher cannot carry out the demanding and indispensable assignment alone. He has to work in cooperation with other stakeholders - the principal, other teachers, students and parents in order to be able to achieve the objectives of delivering good instructions in the classroom setting.

\section{Statement of the Problem}

Teachers are central to contributing towards any enhanced quality and value of classroom experiences. Teachers in public secondary schools are not adequately motivated; there is no contesting the deplorable working condition of the teachers. This problem ranges from working environment through scantily furnished classroom to relatively low remuneration so also non-provision for on-the-job training policy, improve knowledge and skills are not put in place. The problem of this study therefore is to investigate to what extent the career advancement, school relations and support service factors determined the teacher's productivity in Oyo State public secondary schools

\section{Research Questions}

In view of these imperatives, the following research questions were used to guide the study:

1) Are career advancement and school relation factors significant determinants of teacher productivity?

2) What is the relative contribution of career advancement school relation and support service factors to teacher productivity?

3) Which of career advancement, school relation and support service factors can best determine teacher productivity?

\section{The Concept of Productivity}

Productivity is a concept that applies to all aspects of life and therefore means different things to different people. Thus after years of research on productivity, what is clear is that a generally accepted meaning has failed to materialize primarily because of the different and the reference points of the various scholars involved. Mali (1981) identifies four different reference points which he contends have made a single encompassing definition of productivity difficult;

1) A national reference point which views the country as a whole. It takes into account, in a simplistic way, the complex interplay of factors such as labour, capital, management, raw materials and other resources as forces influencing economic goods and services. This reference point describes all effects converging in mix rather than isolating the factors as groups.

2) Another reference point examines productivity in industries. It isolates the factors that relates and affects specific industries such as labour, management, capital and others. This 
emphasis concentrates on the factors that bear exclusively on a particular industry thus; any comparison of firms in different industries will be misleading.

3) Another is the individual firm or organization. The organization has a more visible cause effect relationship of its many factors. Man hour employed and output can be measured and compared to that of the past to determine the efficiency of the firm.

4) A final reference point is the individual worker. The productivity of an individual is affected by work environment and the available tools, processes and equipment.

In a period of timid economic growth and even economic meltdown, achieving productivity gains has acquired a new sense of urgency. This is particularly felt in developing countries where rapid population growth, reduction in export prices of raw materials, growing indebtedness and inflation is cloud the future. Raising productivity can offset the impact of some of these problems and at the same time, help the cause of social development.

Over the years, interest in productivity has taken various forms because of its important role in increasing national welfare; it has now been universally recognized.

A general definition is that productivity is the relationship between the output generated by a production or service system and the input provided to create this output. Thus productivity is defined as the efficient and effective utilization of resources - labour, capital, land, materials, energy, information - in the production of various goods and services.

\section{Career Advancement and Teachers Productivity}

Career advancement refers to factors within the work that teachers find satisfying and therefore could result to advancement on the job. This comprises the level of satisfaction they have on the job, the opportunity they have to improve themselves while on the job. Studies have shown that career advancement on a job can lead to positive work attitudes and behavior (Robins, 1998). Other researchers in Industrial/Organizational literature have also lent credence to the positive effect of personal advancement on job outcomes indicating that perceived advancement on the job lead to happiness, satisfaction and increased level of job performance (McShane \& Von Glinow, 2000; Spector \& Fox, 2006). Morale, Productivity and achievement are also related. Elleberg (1972) found that "where morale was high, schools showed an increase in student achievement. Conversely, low levels of satisfaction and morale can lead to decreased teacher productivity and burnout, which is associated with "a loss of concern for and detachment from the people with when one works, decreased quality of teaching, depression, greater use of sick leave, effort to leave the profession, and a cynical and dehumanized perception of students. In short, the morale of teachers can have far-reaching implications on "student learning, the health of the organization and the health of the teacher"

In its broadest sense, QWL means the sum total of values, both material and non-material, attained by a worker throughout his/her career life. QWL includes aspects of work-related life such as wages and hours, work environment, benefits and services, career prospects and human relations, which is possibly relevant to worker satisfaction and motivation. In fact, the notion of QWL is closely related to the quality of life concept. Parallel concept such as humanization 
of work is also used

Traditionally, career development and success have been defined in terms of occupational advancement, which is also related to psychological success meaning the feeling of pride and personal accomplishment that comes from achieving one's most important goals in life. Most employees are striving for achievement, recognition, and personal growth, in their upward mobility. However, high salary does not ensure a motivated workforce and a higher level of QWL. According to Cascio (2003), the critical factor is not how much a company pays its workers but more importantly, how the pay system is designed, communicated and managed. When the interests of employees and their organizations are aligned, then employees are likely to engage in behavior that goes above and beyond the call of duty and that contributes to organizational effectiveness. This improves both QWL and productivity.

Career satisfaction is defined as the satisfaction individuals derive from intrinsic and extrinsic aspects of their career, including pay, advancement, and developmental opportunities (Greenhaus, Parasuraman, \& Worley, 1990; Rice, Gentile and McFarlin, 1990). This is in contrast to job satisfaction defined as a pleasurable or positive emotional state resulting from an appraisal of one's job or job experiences. Career satisfaction is largely a matter of an individual comparing his/her career and life expectations with those being offered. In shaping such career expectations, there are economic considerations (e.g. compensation and retirement benefits) and occupational and family considerations (e.g. professional satisfaction, job satisfaction, advancement opportunities, relocation, etc.) (Hill, Wilson, \& Sanders, 1998). Whereby a career is more satisfying if it is higher in prestige, income, and power as evaluated upon by managers, it

\section{School support services and Teachers Productivity}

Support services such as library resources, instructional support, technical support, and other facilities that aid the delivery of teaching are essential for effective teaching. These factors have been examined severally and have been shown to be highly consequential for effective delivery of teaching and have also been discovered to aid learning (Dzakiria and Rob, 2002; Hara and Kling, 1999). For instance, instructional methods/materials used for learners, play important roles in their academic performance, and it has either positive or negative influence on their academic performance. Moore (1989), noted that to be successful in delivering education course, teachers must allow learners to interact with minimal intervention; engage the learners in regular assignments in order to monitor their progress; provide specialized attention to the learners with low levels of self-directedness; and help the learners become more self-directed. These can be achieved when needed support services are made available for teachers.

The need to provide a safe work environment for employees has had a long history in human resource management. In Beer (1997) model of human resource management, it is acknowledged that work systems cannot only affect commitment, competence, cost effectiveness and congruence but also have long term consequence for workers' well-being; there is some evidence to indicate that work systems designs may have effects on physical health, mental health and longevity of life itself. Conducive work environment ensures the 
wellbeing of employees which invariably will enable them exert themselves to their roles with all vigor that may translate to higher productivity (Akinyele, 2007). Ezewu (1986) showed that many institutions do not have the physical facilities and those which have do not have current and relevant ones so that practical lessons are taught as theoretical while equipment and materials are borrowed for external examinations, yet such institutions are nevertheless accredited. In his study Ezewu's finds a significant relationship between the utilization of physical and material resources and teaching effectiveness. Udoh (1990) observes that the use of physical and material resources contribute significantly to students' achievement. Oladele (1985) also finds that the quality, quantity and use of physical facilities could influence teaching effectiveness. One would thus infer that if physical and material resources were optimally used, teaching effectiveness would be better enhanced.

\section{School Relation and Teacher Productivity}

School relations is a dimension of QWL in the current study and therefore refers to the subsisting relationship between the teachers and school management in term of the nature of relationship between teachers and head of their department, principal, social fit with the department. Robins (1998) reports that out of all the issues relating to managers skills, relations with employees was rated as the most difficult for them. This issue illustrates the importance of school relation to teachers' outcomes. When the relation between the teachers and the school management is positive, it tend to lead to positive outcomes not only for teachers but also the school management. However, unhealthy relation between teachers and school management is likely to result in poor job performance, low students' performance and general negative work attitudes.

Accordingly, Kohun (1992), defines work environment as "an entirely" which comprises the totality of forces, actions and other influential factors that are currently and, or potentially contending with the employee's activities and performance. Work environment is the sum of the interrelationship that exists within the employees and between the employees and the environment in which the employees work. Brenner (2004) was of the opinion that the ability to share knowledge throughout organizations depends on how the work environment is designed to enable organizations to utilize work environment as if it were an asset. This helps organizations to improve effectiveness and allow employees to benefit from collective knowledge".

Udo and Akpa (2007) asserts that where teachers are adequately involved in decision making process, would be commitment and adequate support with the principal and the realization of school goal will be easy; apathy and opposition within the school will be minimized. Glew et al. (1995) called the system participative decision making and defined it as "higher level individual's effort to provide those at a lower level with a greater voice in organizational performance. The definition makes it clear that in the intelligence quotient literature, participative decision making represents a deliberate change from traditional management in which minority of upper-level management employees make all of the decisions regarding organizational policies and functioning. Jewell (1998) summed up participative decision making as an effort to avoid the "nobody asked" syndrome. He further 
explained it to mean soliciting employee's idea for turning the situation in an organization around. He further opined that along with the expectation that asking, will improve the quality of organizational decision making, it is an expectation that people who participate in decisions that affect them will understand the issues better and accept the decisions more readily.

It can be inferred from the foregoing that principal's leadership behavior has a very positive relationship with school effectiveness. As such, Ibukun (1997) argued that the main task of the principal is to create a conducive atmosphere for the teachers to be able to achieve desired changes in students' learning. Supporting this argument Ijaiya (2000) remarked that teachers in Nigeria express a desire for more participation in decision-making. The way the principal relates with his or her staff could contribute immensely to their effectiveness or otherwise. Researchers have identified certain leadership behaviors used in organizations (Adewole and Olaniyi, 1992; Nias (1994).

This is an increasing politicization of education in Nigeria. At the secondary school level where the local government had some degree of control, there was cases of double loyalties of teachers to both the local and the federal government which control the ministry of education and the local government education authority controlled be different political parties with different philosophies and ideology of education. Education administrator and teachers find themselves torn between divergent loyalties to individuals, parents, government and politicians who have often divergent expectations, demands and values for the system. Besides loyalties, the nature of school administration and facilities provided are dependent on which party is in power. Most of the time this creates an unhealthy work environment for teacher who naturally are non-politicians. Nakpodia (2001).

\section{Research methodology}

The descriptive survey design was adopted forthis study. Basically, it is a simple non-experimental study, employing the simple survey method that enables researcher to generalize result on the entire population being studied from empirical data on sampled population after systematic analysis and description. The study population is the aggregate of all likely respondents from which the sample is selected. In this study, the population consisted of all teachers, vice principals and students of public secondary schools in Oyo State and there are 1095 secondary schools (675 junior secondary school and 420), with 19,251 teachers and 412,215 students. In order to get a manageable sample that would be a good representation of the study, stratified and purposive sampling techniques were used to select 553 secondary schools from the total of 1095 secondary schools in Oyo State. 


\section{Results and Findings}

Research Question 1: Are career advancement, school relation and support service factors significant determinants of teacher productivity?

Table 1: Composite contribution of career advancement and school relation factors to the Determinants of Teacher Productivity

\begin{tabular}{llllllll}
\hline Mode & SS & DF & MS & F & R & $\mathbf{R}^{2}$ & P \\
\hline Regression & 14134.92 & .3 & 2355.82 & 23.87 & 0.34 & 0.12 & $<.05$ \\
Residual & 106872.10 & 1083 & 98.68 & & & & \\
Total & 121007.10 & 1089 & & & & & \\
\hline
\end{tabular}

The result from Table 1 showed that career advancement, support services, and school relations were significant joint determinants of teacher productivity $F(3,1089)=23.87 ; \mathrm{R}^{2}=$ $0.12 ; \mathrm{p}<.05)$. The factors jointly accounted for $12 \%$ variance in teacher productivity. The remaining $88 \%$ could be due to the effect of extraneous variables. Therefore, the significant joint determinants of teacher productivity by career advancement, school relation and support service factors dimensions did not occur as a result of error or chance. However, the joint contribution of the career advancement, school relation and support service factors to teacher productivity though significant, but yet relatively small. What this implies is that there are other salient variables which account for higher variance of teacher productivity than career advancement, school relation and support service factors

Research Question 2: What is the relative contribution of career advancement, school relation and support service factors to teacher productivity?

Table 2: Multiple Regression Analysis Showing Relative Contributions of QWL to Teachers' Productivity

\begin{tabular}{lllllll}
\hline QWL FACTORS & $\mathrm{B}$ & $\mathrm{SE}$ & $\beta$ & $\mathrm{T}$ & $\mathrm{P}$ & Remark \\
\hline Career advancement & 1.18 & 0.17 & 0.36 & 6.82 & $<.05$ & Sig \\
School relations & 0.58 & 0.23 & 0.13 & 2.59 & $<.05$ & Sig \\
Support services & 0.30 & 0.18 & 0.09 & 1.87 & ns & Not Sig \\
\hline
\end{tabular}

The result in Table 2 showed that career advancement $(\beta=0.36 ; \mathrm{t}=6.82 ; p<05)$ and school relations $(\beta=0.13 ; \mathrm{t}=2.59 ; p<.05)$ were significant relative or independent determinants of teacher productivity while support services $(\beta=0.30 ; \mathrm{t}=1.87 ; \mathrm{p}>0.05)$ did not independently or relatively determine teacher productivity.

Research Question 3: Which of career advancement, school relation and support service factors can best determine teacher productivity?

It could be stated that all the factors except support services predicted teacher productivity. However, those which contributions to teachers' productivity were significant as shown in Table 2 were: career advancement $(\beta=0.36 ; \mathrm{t}=6.82 ; \mathrm{p}<.05)$ and school relations 
$(\beta=0.13 \mathrm{t}=2.59 ; p<.05)$.

\section{Conclusion}

Getting high quality job performances from teachers depend on giving them the opportunities for personal growth, career development, achievement, responsibility, recognition, reward and involvement in decision-making among others. Based on the findings of this study, there is the need for all the stakeholders in education to take cognizance of factors like career advancement and school relations. All these and more make the productivity. As widely accepted that no nation or educational system can rise above the quality of their teachers, these factors focuses on humanization of work which in turn improves the life of workers on the job by creating the kind of work environment that can contribute to workers' productivity must be adopted by the government.

The result of this study supports the proposition that the degree of satisfaction in the factors considered is related to the degree the individual believes his or her success criteria have been met, especially if the individual places great importance on these criteria which include pay, respect, personal growth and family life balance. This supports the materialistic work ethic that place strong emphasis on corporate power, income and personal growth as parts of their growth driving factors.

\section{Discussion of implications}

Premised on the finding that career advancement and school relation factors will most predict teacher productivity? It is hereby recommended that government, PTA, and stakeholders should Endeavour to put in place things that will improve teachers' productivity. This should comprise monetary and non-monetary packages that could bring about improved services.

With respect to the positive composite effect of the factors on teacher productivity, the government should take advantage of this to enhance teacher output. This should be by comprehensively upgrading the composite variables to achieve the desired objective of improved teacher productivity. Further, given the high rating of career advancement and school relation factors to teacher productivity due consideration should be given to pertinent issues relating to them. 


\section{References}

Abayowa, S. (2004). People issues in a total quality environment: team working leadership and motivation. A paper presented at a training programme on TQM organized by Gateway Bank Plc.

Adepoju, D.G. (2004). Sources of finance for school. Role of banks, insurance company and other institutions. Being a paper presented at gateway bank Plc. training school.

Adesokan, O.O. (2000). Teacher effectiveness. A tool for a functional universal basic education [UBE] programme in a democratic Nigeria. Paper presented to the conference on Planning and Administration for a Successful Implementation of the UBE in Nigeria. National Institute of Educational Planning and Administration in Ondo.

Adewole E.E., \&Olaniyi, W.O. (1992). School organization and management. Ifeoluwa Nig. Ltd. Ondo. 38-56.

Ajayi, I. A., \& Adeosun, R. O. (2004). Towards the effective management of primary education in Ekiti state. Journal of Contemporary Issues in Education, 2(1), 104-214.

Ajayi, T. (2000). Planning and administration of universal basic education UBE in Nigeria. $A$ publication of the National Institute for Educational Planning and Administration, 3(4), 102-120.

Akinyele S. T. (2007). A critical assessment of environmental impact on workers'productivity in Nigeria. Res. J. Bus. Manage, 1(1), 50-61. http://dx.doi.org/10.3923/rjbm.2007.50.61

Akporehe, D. A. (2011). The impact of environment on productivity in secondary schools. African Journal of Education and Technology, 1(1), 116-122.

Aremu, A.O. (2000). Academic performance 5 factor inventory. Ibadan: Stirling-Horden Publishers.

Beer. (1997). Human resource management. 36, 49-56.

Brenner. (2004). Workers physical surrounding impact. Bottom line Accounting: Press Com.

Cascio, W.F. (2003). Managing human resources: productivity, quality of work life, profits $\left(6^{\text {th }}\right.$ ed $)$. New York: McGraw-Hill

Dzakiria B., \& Rob A. (2002). Teacher-Learner interactions in distance education; a case of two Malaysian Universities. Journal of Distance Education, 4(3), 56.

Ellenberg, F.C. (1972). Factors affecting teacher morale. NASSP Bulletin, 56(12), 76.

Ezekwesili, O. (2006). Human capital, a strategic asset for national development. A lecture delivered at the convocation of Federal University of Technology Oweri.

Ezewu, E.E. (1986). An analysis of the causes of mass failure at the general certificate of education (ordinary level) examination in Nigeria. In mass failure in public 
examinations. University of Ibadan, Faculty of Education.

Fadipe, J.O. (2000). An overview in education and productivity in Nigeria. In education and productivity in Nigeria. Fagbamigbe E.O. and Durosaro D.O. (Eds).Ilorin Hay tee Press and Publishing Chapter 1, 1-8.

Glew D.J., O’Leary-Kelly A.M., Griffin R.W., \&Van fleet D.D. (1995). Participation in organizations: A preview of the issues and proposed framework for future analysis. Journal of Mgt, 21, 395-421. http://dx.doi.org/10.1177/014920639502100302

Greenhaus, J.H., Parasuraman, S., \& Wormley, W.M. (1990). Effects of race on organizational experience, job performance evaluations, and career outcomes. Academy of Management Journal, 16, 129-137.

Hallak, J. (1990). Investing in the future: Setting educational priorities in the developing world. Paris: IIEP and Pergamon Press.

Hara, N., \& Kling, R. (1999). Student's frustrations with web-used education course. First Monday 4, 12. Retrieved April 6, 2002 from http://firstmonday.org/issues/issues412/hara/index.html

Hill, C., Wilson, T.O., \& Sanders, D.Y. (1998). In QWL, employee performance and career growth opportunities: A literature review. International journal of multidimensional research, 2(2).

Ibukun, W.O. (1997). Educational Management: Theory and Practice. Lagos: Green line publishers.

Ijaiya N.Y. (2000). Failing Schools' and National Development: Time for Reappraisal of School Effectiveness in Nigeria. Niger. J. Education. Research. Evaluation, 16- 42.

Ilori Olanrewaju. (1995). School environment, teacher characteristics and teaching process as factors of teacher productivity in selected Nigerian Unity School. Ph.D. thesis, Department of Educational Management, University of Ibadan, Ibadan.

Jaiyeoba, A.O. (1997). The National Policy on Education and its impact on secondary school administration in Oyo State. Africa Journal of Educational Management. Kraft Book Ltd Ibadan, 2(5), 155-159.

Jewell, L.N. (1998). Contemporary industry and organizational psychology. Third Edition Books/Cole Publishing Company.

Kohun S. (1992). Business Environment. Ibadan: University Press 3rd (Ed): Harloa Pearson Educational Limited.

Mali. (1978). Improving total productivity. New York. John Wiley and Sons.

Mcshane, S.L., \& Von Glinow, M.A. (2000). Organizational behavior. McGraw-Hill. Higher Education, 709.

Moore, M.G. (1989). Editorial: Three types of interaction. American Journal of Distance 
Education, 3(2), 1-6. http://dx.doi.org/10.1080/08923648909526659

Nakpodia ED. (2000). Educational Administration a new approach. Nigeria: Jonokase Nig. Co. Warri.

Nias, J. (1994). Teachers appear to respond positively to a leader who knows what he wants and gets the job done. J. Educ., 42-54.

Obayan, P.A.I. (2006). Teaching without teacher. A paper delivered at Adeniran Ogunsanya College of Education, Punch Newspaper July 5, 35.

Odunuga, J.B., \& Ajila, P.K. (2000). Measuring teachers' productivity and primary school quality: An evaluation of concept and issues. Education and productivity in Nigeria, Fagbamiye E.O. \& D.O. Durosaro (eds) Ilorin Hayttee Press and Publishing Company Limited Chapter 3: 16-31.

Ogomudia, O. (2008). Ogomudia canvasses investment in education. The Punch Newspaper October 23:8.

Ogunsanya, M. (1981). Teacher job satisfaction and productivity as factors of academic goal achievement in Oyo State Secondary Schools. PhD Thesis, Department Educational Management. University of Ibadan, Ibadan.

Oladele, J.O. (1985). Teacher effectiveness: A review of opinions on the subject. Journal of Research in Curriculum JORCC 3.1.

Omotoso, F. (2007). Educationist shows way forward for public schools. The Punch Newspaper, Friday February 9, 31-33.

Rice, R.W., Gentile, D.A., \& Mcfarlin, D.B. (1991). Facet importance and job satisfaction. Journal of Applied Psychology, 76, 31- 39. http://dx.doi.org/10.1037/0021-9010.76.1.31

Robbins, S.P. (1998). Organisational Behaviour: Concepts Controversies and Applications. NJ: Prentice Hall.

Spector, P.E., \& Fox, S. (2006). The many roles of control in a stressor-emotion theory of counterproductive work behaviour in Pamela L. Perreme (Ed.) Employee Health, Copying and methodology (Research in Occupational Stress and Well-being 5 Emerald group Publishing Limited, 171-201.

Udoh S.U., \& Akpa G.O.(2007). Educational Administration in Nigeria. Theory and Practice. ISBN 978-236-049-X.

Udor, G.E. (1990). An assessment of implementation of the junior secondary school curriculum in AkwaIbomState. M.Ed. Project University Benin, Benin City.

Umeh P.O.C. (1997). Increasing Productivity in Nigeria: Proceedings from the 1st National Conference in Nigeria, National Productivity Centre Abuja.

West African Examination Council 2007. Statistics of Examination Result. WAEC Publication. WAEC Lagos Nigeria. 


\section{Copyright Disclaimer}

Copyright reserved by the author(s).

This article is an open-access article distributed under the terms and conditions of the Creative Commons Attribution license (http://creativecommons.org/licenses/by/3.0/). 